Omni-Akuatika, 14 (2) : 91 -99, 2018
ISSN: 1858-3873 print / 2476-9347 online
Research Article
journal homepage: http://ojs.omniaquatika.net

\title{
The Effects of Papain Enzyme Supplement in Feed on Protein Digestibility, Growth and Survival Rate in Sangkuriang Catfish (Clarias sp)
}

\author{
Diana Rachmawati ${ }^{{ }^{*}}$, Istiyanto Samidjan ${ }^{1}$ \\ ${ }^{1}$ Aquaculture Department of Fisheries, Faculty of Fisheries and Marine Sciences, Diponegoro University, \\ Jl. Prof. Soedarto, SH, Tembalang, Semarang 50275, Indonesia \\ ${ }^{*}$ Corresponding author: dianarachmawati1964@gmail.com
}

\begin{abstract}
The study aimed to assess the effects of Papain Enzyme Supplement in Feed on Protein Digestibity, Growth and Survival Rate of Sangkuriang Catfish (Clarias sp). Fingerlings used in the study were acquired from the Center for Freshwater Hatchery and Aquaculture, Muntilan, Central Java, Indonesia. The fingerlings had average weight of $3.43 \pm 0.50 \mathrm{~g} / \mathrm{fish}$. Completely Randomized Design was used in the experiments with 5 (five) treatment and 3 (three) repetitions. The experimental feed contained $31 \%$ of protein and $252.06 \mathrm{Kcal} / \mathrm{g}$ of energy. Various doses of the addition of papain enzyme were incorporated into the feed, those doses were A $(0 \mathrm{~g} / \mathrm{kg}$ feed), B $(2 \mathrm{~g} / \mathrm{kg}$ feed), C $(4 \mathrm{~g} / \mathrm{kg}$ feed), D (6 g/kg feed) and $E(8 \mathrm{~g} / \mathrm{kg}$ feed). Parameters of digestibility of protein (ADC $)$, relative growth rate (RGR), efficiency of feed utilization (EFU), feed conversion ratio (FCR), protein efficiency ratio (PER), survival rate (SR) and water quality were evaluated. The papain enzyme supplement significantly $(P<0.01)$ influenced on ADCp, RGR, EFU, FCR, and PER, otherwise SR of catfish was insignificantly affected by the papain enzyme supplement. The best treatment result was the addition of $6 / \mathrm{kg}$ feed papain enzyme (treatment D). The study concluded that the optimum dose of the papain enzyme supplement for ADCp, EFU, FCR, PER and RGR were 5.65, 5.62, 6.0, 5.66, $6.0 \mathrm{~g} / \mathrm{kg}$ feed respectively. Water quality during study was still in favorable condition for nurturing Sangkuriang catfish (Clarias $s p)$.
\end{abstract}

Keywords: papain enzyme, apparent protein digestibility, feed utilization efficiency, growth, Sangkuriang catfish, Clarias $s p$

\section{Introduction}

Sangkuriang Catfish (Clarias sp) is one of fresh water fish that has high economic value. The success of the Sangkuriang Catfish (Clarias $s p$ ) production highly depends on the availability of feed. Sangkuriang Catfish (Clarias sp) was generated through genetically modified inbreeding between African Catfish (Clarias gariepinus). Sangkuriang Catfish (Clarias sp) has some advantages, such as fast growth, a lot of eggs, disease resistance, high yiled, and easy to raise (BBPBAT, 2010).

One of the problems in this aquaculture is inefficiency of feed utilization. The share of feed cost is between $40 \%$ and $60 \%$ of total cost (Olmos et al., 2011). Efficiency of feed utilization can be improved by adding papain enzyme in feed (Kazerani et al., 2011). Patil and Singh (2014); Amri and Mamboya (2012);
Farraq et al. (2013) and Rostika et al. (2018) reported that the papain enzyme was able to break down long chained amino acids into digestible amino acids.

Patil and Singh (2014) found that the addition of papain enzyme in the feed of $0,1 \%$ can give the best growth of shrimp (Macrobrachium rosenbergii). Meanwhile the best growth and the best protein efficiency in Labeo rohita fingerlings was achieved at the dose of $10 \mathrm{~g}$ papain enzyme per $\mathrm{kg}$ feed (Khati et al. (2015). Muchlisin et al. (2016) also reported in keureling fish that the best dose was $27,5 \mathrm{mg} / \mathrm{kg}$ feed. Those studies show that different species of fish need different dose of papain enzyme. Utomo et. al. (2013) also found that feed made of fish meal in the Sangkuriang Catfish (Clarias sp) brought about the best 
growth, the best feed efficiency, and the highest survival rate as high as $5.56 \%$, $63,15 \%$, and $100 \%$ respectively. There were still lacks of studies in Sangkuriang Catfish (Clarias $s p$ ); therefore study of papain enzyme supplement in the feed on protein utilization in the feed and growth of Sangkuriang Catfish (Clarias sp) was still needed.

\section{Materials and Methods}

\section{Experimental design}

The experiment was conducted in the Laboratory of Aquaculture, Department of Aquaculture, Faculty of Fishery and Marine Science, Diponegoro University, starting from October 2017 until January 2018. The study used Completely Randomized Experimental Design. There were 5 (five) treatments. Every treatment had 3 (three) repetitions. The treatments used various doses of papain enzyme supplement. Those treatments were $A$ (0 g/kg feed), B ( $2 \mathrm{~g} / \mathrm{kg}$ feed), C ( $4 \mathrm{~g} / \mathrm{kg}$ feed), D (6 g/ $/ \mathrm{kg}$ feed) and E ( $8 \mathrm{~g} / \mathrm{kg}$ feed). Modified method of Farrag et al. (2013) was used to assign the dose of papain enzyme supplement. They found that the best dose for Oreochromis niloticus growth was $6 \mathrm{~g} / \mathrm{kg}$ feed. The consideration to prescribe dose levels in this study was to identify the effects of various doses of papain enzyme below and above of optimum dose in the Oreochromis niloticus.

\section{Sampled fish preparation}

Sangkuriang Catfish (Clarias sp) fingerlings were acquired from the Center for Freshwater Hatchery and Aquaculture, Muntilan, Central Java, Indonesia. The fingerlings had average weight of $3,43 \pm 0,50$ $\mathrm{g} / \mathrm{fish}$. Before the treatment, the fingerlings had adapted for one week in which the fingerlings had only been given feed without papain enzyme supplement. Then the fingerlings fasted for one day to neutralize previous treatment (Rachmawati et al., 2017). At the beginning of the study the fingerlings were weighed. The fingerlings were cultured for 49 days with the density of 1 (one) fish per liter (Dasuki et al., 2013).

\section{Container preparation}

Aquariums with the dimension of $50 \times 50 \times 30 \mathrm{~cm}^{3}$ were used in the study. Every aquarium was installed with an aerator. Disinfectant was used to clean containers, tools, and media culture. The disinfectant was $5 \mathrm{mg} / \mathrm{L}$ Chlorine $(\mathrm{Cl} 2)$. After that they were kept one day unused. Natrium Triosulphate $\left(\mathrm{Na}_{2} \mathrm{SO}_{3}\right) 3 \mathrm{mg} / \mathrm{L}$ was applied to neutralize the disinfectant. Then they were washed with freshwater (APHA, 1990). After sterilizing the containers, tools, and media culture, freshwater was used to fill the containers as needed.

\section{Feed preparation}

Feed for the study contained $31 \%$ proteins and $252 \mathrm{Kcal} / \mathrm{g}$ feed. The feed was made of fish meal, soy meal, corn meal, rice bran, wheat flour, fish oil, vitamin mix, $0.5 \%$ $\mathrm{Cr}_{2} \mathrm{O}_{3}$, and papain enzyme. Fish meal and soy meal were as source of protein, while corn meal, rice bran, and wheat flour as source of carbohydrate. A source of fat was fish oil. $0.5 \% \quad \mathrm{Cr}_{2} \mathrm{O}_{3}$ was used as an indicator of digestibility (NRC, 1993). Papain enzyme with a brand name "NEWZIME" was produced by Center for Brackish Water Aquaculture Jepara. The ingredient contents of the feed were analyzed using proximate analysis AOAC (1990). The results were shown in the Table 1. Feed preparation was based on NRC (1993). First soy meal was homogeny mixed with papain enzyme. To get hydrolyzed the mixed feed was marinated for one hour. Then the papain enzymized soy meal was mixed with all the ingredients of protein and carbohydrate sources, starting from the least amount to the most. Meanwhile, vitamin, mineral and fish oil were dilated with water. Then the dilated vitamin, mineral and fish oil were evenly mixed with all ingredients. All mixed ingredients were molded into pellets. Then the pellets were dried. Before pellets being used, the pellets were stored in the refrigerator. Feeding was given in an incremental amount until at satiation. 
Table 1. The feed composition and the proxymate analysis results

\begin{tabular}{|c|c|c|c|c|c|}
\hline \multirow[t]{2}{*}{ Ingredients (\%) } & \multicolumn{5}{|c|}{ Treatment } \\
\hline & A & $\mathrm{B}$ & $\mathrm{C}$ & $\mathrm{D}$ & $E$ \\
\hline Papain & 0 & 2 & 4 & 6 & 8 \\
\hline Fish meal & 34.76 & 34.55 & 34.32 & 34.20 & 34.08 \\
\hline Soybean meal & 34.32 & 34.22 & 33.99 & 33.77 & 33.55 \\
\hline Corn meal & 10.52 & 9.79 & 8.71 & 7.44 & 6.17 \\
\hline Rice bran & 8.03 & 6.87 & 6.82 & 6.78 & 6.74 \\
\hline Dextrine & 8.37 & 8.57 & 8.16 & 7.81 & 7.46 \\
\hline Fish Oil & 1.5 & 1.5 & 1.5 & 1.5 & 1.5 \\
\hline Corn Oil & 0.5 & 0.5 & 0.5 & 0.5 & 0.5 \\
\hline Min.Vit & 1 & 1 & 1 & 1 & 1 \\
\hline CMC & 1 & 1 & 1 & 1 & 1 \\
\hline TOTAL & 100 & 100 & 100 & 100 & 100 \\
\hline \multicolumn{6}{|l|}{ Results Proximate Analysis } \\
\hline Protein (\%) & 31.32 & 31.37 & 31.37 & 31.40 & 31.40 \\
\hline Fat $(\%)$ & 7.03 & 7.04 & 7.04 & 7.04 & 7.04 \\
\hline BETN (\%) & 32.75 & 32.85 & 32.81 & 32.29 & 32.29 \\
\hline Energy (kkal/g) & 252.06 & 252.02 & 252.27 & 250.04 & 250.04 \\
\hline Ratio E/D (kkal/g Feed) & 8.02 & 8.05 & 8.03 & 8.02 & 8.02 \\
\hline
\end{tabular}

a The values for $1 \mathrm{~g}$ protein, $1 \mathrm{~g}$ fat, and $1 \mathrm{~g}$ carbohydrate equal $3.5 \mathrm{kcal}, 8.1 \mathrm{kcal}$, and $2.5 \mathrm{kcal}$ respectively. The calculation was based on Digestible Energy (Wilson, 1982)

${ }^{\mathrm{b}}$ The optimal E/P ratio for growth ranges from $8 \mathrm{kcal} / \mathrm{g}$ to $12 \mathrm{kcal} / \mathrm{g}$ (De Silva,1987).

${ }^{c}$ Animal Nutrient Laboratory, Faculty of Husbandry and Agriculture, Diponegoro University (2017)

\section{Measured parameters}

Parameters evaluated in the study were digestibility of protein $\left(A D C_{P}\right)$ based on the study of Fennuci (1981), efficiency of feed utilization (EFU), feed conversion ratio (FCR), and protein efficiency ratio (PER) based on the research of Takeuchi (1988), relative growth rate (RGR) and survival rate (SR) based on the Tacon (1995) study, and water quality. To measure the $\mathrm{pH}$ used Jenway 3510, while JENWAY 970 was used to measure dissolved oxygen (DO). Temperature and ammoniac content were measured using HANNA: $\mathrm{HI}$ 8633. To measure the $\mathrm{Cr} 2 \mathrm{O} 3$ content in the feed and feces used Colorimetric method (Fenucci, 1981). The parameters were calculated using equation as follows :

$A D C_{P}=100 \times[(\% \mathrm{Cr} 2 \mathrm{O} 3$ feed $\mathrm{X} \%$ protein feces) $/\left(\% \mathrm{Cr}_{203}\right.$ feces $\mathrm{X} \%$ protein feed $)$ ]

$E F U=\{($ Final weight - Initial weight $) /$ the amount of feed consumed $\times 100 \%$

$\mathrm{FCR}=$ the amount of feed consumed $/$ $[($ Final weight + Total weight fish death) Initial weight]\}

PER $=\{($ Final weight - Initial weight $) /$ (the ampunt of feed consumed $X$ Prptein content of feed) $\} \times 100 \%$.
$R G R=\{$ (Final weight - Initial weight) $/$ (initial weight $x$ time experiment) $\}$ X $100 \%$

$S R=($ Final count $/$ Initial count $) \times 100 \%$

\section{Statistical analysis}

To evaluate the effects of papain enzyme supplement in the feed on ADC $P$ RGR, EFU, FCR and PER of Sangkuriang catfish fingerlings used analysis of variance (ANOVA). If the analysis of variance was significant $(p<0.05)$ or highly significant $(p<0.01)$, Duncan test was applied to find out the mean of the treatment (Steel et al. 1996). To determine optimal dose of papain enzyme used polynomial orthogonal test using SAS9 and Maple12. Descriptive analysis was used to explain water quality data.

\section{Results and Discussion}

\section{Parameters data}

The results of digestibility of protein $\left(A D C_{P}\right)$, relative growth rate (RGR), Efficiency of feed utilization (EFU), feed conversion ratio (FCR), protein efficiency ratio (PER), and survival rate $(\mathrm{SR})$ were presented in the Table 2. 
Table 2. The Values of digestibility of protein $\left(A D C_{P}\right)$, relative growth rate $(R G R)$, Efficiency of feed utilization (EFU), feed conversion ratio (FCR), protein efficiency ratio (PER), and survival rate (SR) of Sangkuriang Catfish Fingerlings

\begin{tabular}{lccccc}
\hline \multirow{2}{*}{ Parameters } & \multicolumn{5}{c}{ Treatments } \\
\cline { 2 - 6 } & $\mathrm{A}$ & $\mathrm{B}$ & $\mathrm{C}$ & $\mathrm{D}$ & $\mathrm{E}$ \\
\hline ADC & $50.27 \pm 0.03^{\mathrm{a}}$ & $63.42 \pm 0.03^{\mathrm{C}}$ & $72.38 \pm 0.04^{\mathrm{b}}$ & $82.13 \pm 0.05^{\mathrm{a}}$ & $70.15 \pm 0.05^{\mathrm{b}}$ \\
\hline EFU $(\%)$ & $50.32 \pm 0.06^{\mathrm{c}}$ & $60.26 \pm 0.07^{\mathrm{b}}$ & $67.15 \pm 0.26^{\mathrm{b}}$ & $75.09 \pm 0.75^{\mathrm{a}}$ & $65.25 \pm 0.57^{\mathrm{b}}$ \\
\hline FCR & $2.58 \pm 0,15^{\mathrm{c}}$ & $2.26 \pm 0,14^{\mathrm{b}}$ & $2.10 \pm 0,22^{\mathrm{b}}$ & $1.68 \pm 0,13^{\mathrm{a}}$ & $2.20 \pm 0,21^{\mathrm{b}}$ \\
\hline PER & $1,25 \pm 0,05^{\mathrm{c}}$ & $1,87 \pm 0,26^{\mathrm{b}}$ & $2,14 \pm 0,27^{\mathrm{b}}$ & $2.56 \pm 0,06^{\mathrm{a}}$ & $2,10 \pm 0,13^{\mathrm{b}}$ \\
\hline RGR (\%/day) & $2.25 \pm 0.07^{\mathrm{d}}$ & $4.26 \pm 0.06^{\mathrm{C}}$ & $5.89 \pm 0.06^{\mathrm{b}}$ & $7.05 \pm 0.07^{\mathrm{a}}$ & $5.24 \pm 0.04^{\mathrm{b}}$ \\
\hline SR (\%) & $88.33 \pm 0.77^{\mathrm{a}}$ & $90.33 \pm 0.26^{\mathrm{a}}$ & $88.33 \pm 0.77^{\mathrm{a}}$ & $92.33 \pm 0.77^{\mathrm{a}}$ & $88.33 \pm 0.78^{\mathrm{a}}$ \\
\hline
\end{tabular}

Note: The Values with the same superscripts in the column show that there was no difference

The results of analysis variance show that the papain enzyme supplement in the feed significantly $(P<0.01)$ increased $A D C p$ in the Sangkuriang catfish fingerlings, as presented in the Table 2. It was thought that the papain enzyme can hydrolyze protein. The increase was indicated by the boost of $A D C p$ value after the papain enzyme has been added into the feed with the doses of $2-8 \mathrm{~g} / \mathrm{kg}$ feed). Similar result was reported by Spinelli et al. (1983); Dabrowski and Glogowski (1977). They stated that protein digestibility went up as the papain enzyme supplement increased. It was due to the activity of papain enzyme to dephosphorize phytate acid and phosphor to provide more readily available phosphor to absorb, as reported by Lanari et al. (1998). The treatment D $\left(6 \mathrm{~g} / \mathrm{kg}\right.$ feed) gave the highest $A D C_{P}$ value with the value of $82.13 \%$. The highest ADCp thought that the papain enzyme dose was the appropriate amount to hydrolyze amino acids, therefore it can provide digestible protein for the catfish. This finding was supported by the Steffens (1989) study that high protein digestibility meant there was more protein that can be digested by the fish. The next best doses were followed by $\mathrm{C}(4 \mathrm{~g} / \mathrm{kg}$ feed), $\mathrm{E}$ (8 $\mathrm{g} / \mathrm{kg}$ feed), B (2 g/kg feed) and A (0 g/ $/ \mathrm{kg}$ feed) as much as $72.38 \%$,

The best dose of $6 \mathrm{~g} / \mathrm{kg}$ feed also generated the highest EFU $(75,09 \%)$ and the lowest FCR $(1,68)$. It can be concluded that the higher the protein digestibility brought about the higher EFU and lower FCR. The same results were also discovered by Singh et al., (2011), Farraq et al. (2013), Muchlisin et al. (2016), Mo et al. (2016) and Rostika et al. (2018). The polynomial orthogonal test show that the relationship between papain enzyme and ADCp (Figure 1) has quadratic form $Y=-$ $0.883 x^{2}+9.990 x+48.90, R^{2}=0.93$. The optimum $A D C_{p}$ was generated at the dose of $5.65 \mathrm{~g} / \mathrm{kg}$ feed with the value of $77.15 \%$.

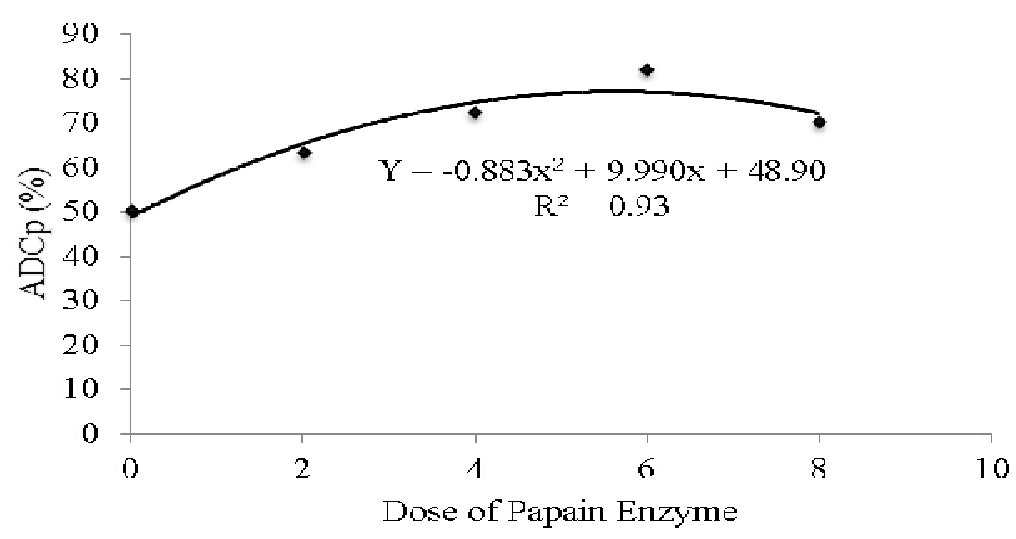

Figure. 1. The relationship between papain enzyme supplement in the feed and $A D C_{P}$ of Sangkuriang Catfish (Clarias sp) fingerlings 
Efficiency of feed utilization (EFU) is an indicator for feed utilization. High value of EFU indicated that the feed can be well utilized to grow the fish (Tacon, 1995). The results of Analysis of Variance show that papain enzyme supplement was highly significant $(P<0.01)$ on EFU of Sangkuriang Catfish (Clarias sp) fingerlings. Table 2 presented the results and show that the treatment $D(6 \mathrm{~g} / \mathrm{kg}$ feed $)$ gave the highest value of EFU (75\%), while the lowest value of EFU (50.32\%) reached by the treatment $A(0 \mathrm{~g} / \mathrm{kg}$ feed $)$. The high value of EFU was suggested the amount of papain enzyme supplement was appropriate to hydrolyze polypeptide protein into amino acid; therefore, they were easily absorbed by the fish. This phenomenon would help the fish to utilize most energy for growth, not for metabolism. The finding was also supported by the finding of the studies by Mo et al. (2016) and Rosita et al. (2018). They found that papain enzyme can increase the breakdown and digestibility feed ingredients that made of plant based feed.

The high value of efficiency of feed utilization show that the feed was high quality, therefore the fish can optimally digest the feed (Huet, 1970). Efficiency of feed utilization was an indicator for feed utilization; the low conversion ratio means nutrient has been digested and absorbed optimally by fish (Steffens, 1989). Their findings were in line with this study that the best dose of $6 \mathrm{~g} / \mathrm{kg}$ feed (treatment D) also generated the highest EFU $(75,09 \%)$ and the lowest FCR $(1,68)$. Muchlisin et al. (2016) also reported that Keureling Fish (Tor tambra) that had been given by papain enzyme supplement had high value of EFU. The 27,5 mg papain enzyme addition for every $\mathrm{kg}$ feed was the best dose for Keureling fish (Tor tambra), therefore the treatments brought about the highest values of SGR $(2,19 \%$ per day), EFU (53,44\%), FCR (1.87), and $A D C_{P}$ $(53.44 \%)$. Figure 2 presented the relationship between papain enzyme and EFU.The relationship had a quadratic pattern as the following: $Y=-0.687 x^{2}+7.735 x+49.17, R^{2}=$ 0.91 . The equation resulted in the optimum dose of EFU at the dose of $5.62 \mathrm{~g} / \mathrm{kg}$ feed with the maximum value $70.94 \%$.

The doses of 2-8 $\mathrm{g} / \mathrm{kg}$ feed of the papain enzyme supplement improved metabolism; in turn it brought about FCR lower. The dose of papain enzyme supplement of $6 \mathrm{~g} / \mathrm{kg}$ feed yielded the lowest FCR. Similar result found in Sing et al. (2011) study, Chanos channos fed $2 \%$ papain enzyme supplement generated the lowest FCR. Patil and Singh, (2014) found that the $0,1 \%$ papain enzyme supplement caused the growth and efficiency feed utilization go up on post larvae of $M$. rosenbergii. Khati et al. (2015) also reported that the dose of $10 \mathrm{~g} / \mathrm{kg}$ feed of papain enzyme supplement increased feed digestibility and reduced FCR of Labeo rohita. Muchlisin et al. (2016) reported that the best dose of papain enzyme for keureling fish (Tor tambra) on FCR was $27,5 \mathrm{mg}$ papain enzyme supplement per $\mathrm{kg}$ feed.

Figure 3 presented the relationship between papain enzyme and FCR. The equation was approached using polynomial orthogonal test. The equation form was in quadratic as $Y=0.0254 x^{2}-0.2699 x+2.6349$, $\mathrm{R}^{2}=0.77$. From the equation, the optimum dose was derived. The optimum dose was 6 gram papain enzyme supplement per $\mathrm{kg}$ feed with the value of 1.68 .

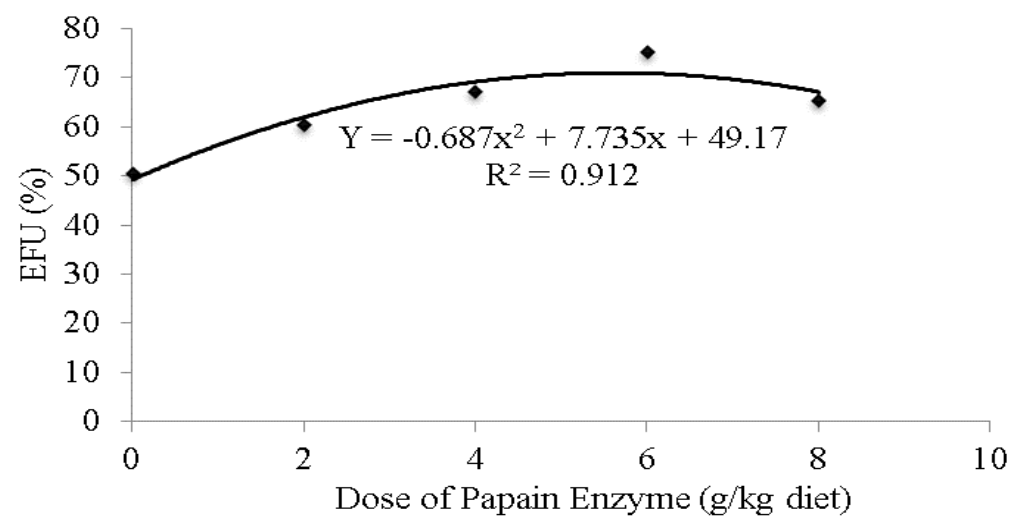

Figure. 2. The relationship between papain enzyme supplement in the feed and EFU of Sangkuriang Catfish (Clarias $s p$ ) fingerlings 


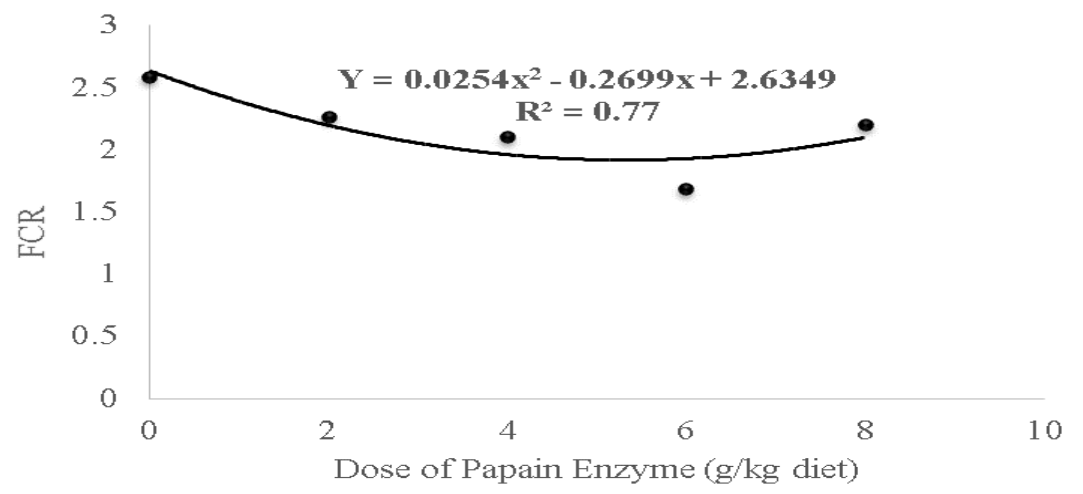

Figure. 3. The relationship between papain enzyme supplement in the feed and FCR of Sangkuriang Catfish (Clarias $s p$ ) fingerlings

Manush et al. (2013) stated that Protein efficiency ratio (PER) was an indicator to show how good protein in the feed was able to provide amino acids for fish growth. Table 2 depicted that the value of PER (1.87-2.56) went up as the papain enzyme supplement $(2-8$ $\mathrm{g} / \mathrm{kg}$ feed) increased. The treatment D $(6 \mathrm{~g} / \mathrm{kg}$ feed) resulted in the highest PER (2.56). It was suggested that the availability of protease enzyme improved PER. As Singh et al. (2011) found that papain enzyme supplement had protein digestibility go up. It was because of the increase of digestible protein and protease enzyme. Khati et al. (2015) also reported that papain enzyme was a type of protease enzyme that can hydrolyze protein, in turn it provided more digestible protein. Papain enzyme acted as a biological catalyst which can improve quality feed. Papain enzyme can also reduce negative effects from phytate acid in plant based feed.

The lowest value of PER (1.25) was obtained from treatment $A(0 \mathrm{~g} / \mathrm{kg}$ feed $)$. The lowest value of PER was suggested by lack of protease enzyme that can help to digest plant based protein. If there was lack of the enzyme, the feed cannot be absorbed well by the fish. The finding was supported by Mo et al. (2016) study that plant based protein such as soy meal has anti-nutrient that inhibited protease release and methionine that reduced amino acids absorption. Singh et al. (2011) suggested in their study that papain enzyme supplement was highly effective to reduce anti-nutrient in plant based feed, as it was known that the antinutrient in plant based feed can reduce growth of fish.

PER value highly depends on the quality and quantity of the feed. The higher PER would give higher protein efficiency, in turn it would increase growth. This discovery was also reported by Hepher (1988). The value of PER was also influenced by the ability of the fish to digest the feed. The polynomial orthogonal test on PER resulted in the quadratic relationship between papain enzyme and PER (Figure 4) with the equation of $Y=-$ $0.0359 x^{2}+0.4066 x+1.2189, R^{2}=0.93$. The equation show that the optimum dose of papain enzyme for PER was 5.66 gram per $\mathrm{kg}$ feed with the PER value of 2.37 .

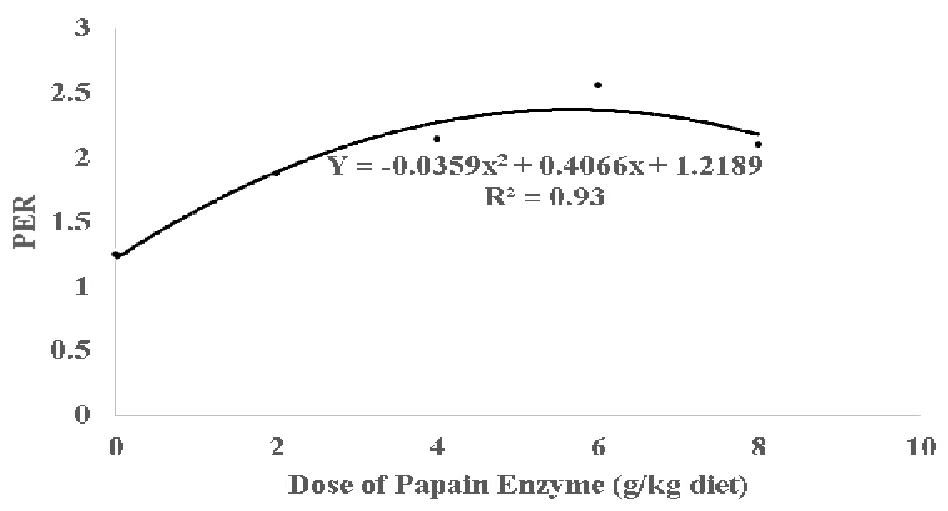

Figure 4. The relationship between papain enzyme supplement in the feed and PER of Sangkuriang Catfish (Clarias sp) fingerlings 
Table 2. presented the results that papain enzyme supplement in the feed could improve the value of RGR. The best dose of papain enzyme supplement for RGR of Sangkuriang Catfish (Clarias sp) was $6 \mathrm{~g} / \mathrm{kg}$ feed (treatment D) with the value of $7.05 \% /$ day, while the lowest value of RGR (2.25\%/day) was in the treatment $A(0 \mathrm{~g} / \mathrm{kg}$ feed). The high RGR in the treatment $D$ was suggested that the amount of papain enzyme supplement was suitable to break down protein in the feed from long chained peptide into short chained peptide; therefore it was easily absorbed by fish. Treatment $A$ with zero dose of papain enzyme has a lack of enzyme to hydrolyze long chained peptide into short chained peptide, therefor it caused low in RGR. As reported by Wong et al (1996) that papain enzyme was protease enzyme that would break down long chained peptide into short chained peptide that an essential factor in the protein digestibility, nutrient absorption, and growth of fish. Studies of papain enzyme supplement on some species were also conducted, such as on Chanos channos (Singh et al., 2011), M. rosenbergii (Patil and Singh, 2014), Oreochromis niloticus (Farraq et al. 2013; Manguti et al., 2014; Rostika et al. 2018), Labeo rohita (Khati et al., 2015), Epinephelus bleekeri (Mo et al., 2016) and keureling fish (Tor tambra) (Muchlisin et al., 2016). Figure 5 presented the graph that show the relationship between papain enzyme and $R G R$ in the form of quadratic equation such $Y=$ $-0.144 x^{2}+1.597 x+2.025, R^{2}=0.94$. The equation yielded an optimum dose for RGR at 6 $\mathrm{g} / \mathrm{kg}$ feed with the value of $7.05 \% /$ day.

At the dose of 8 gram papain enzyme per $\mathrm{kg}$ feed, the values of PER and RGR decreased. The decrease was becauase the dose has passed the optimum dose. When the dose passed the optimum level, the availability of amino acids were becoming too much. Too much amino acids can have negative effect on PER and RGR.

Analysis of Variance (ANOVA) show that papain enzyme supplement did not significantly $(P>0.05)$ influence on survival rate $(S R)$ of Sangkuriang Catfish (Clarias $\mathrm{sp}$ ) fingerlings. The finding was in accordance to the results of Dabrowski and Glogowski (1977) studies. They reported that the addition of papain enzyme in the feed did not significantly influence survival rate of the fish. Yakuputiyase (2013) also suggested similar result, but the quality of the media culture that influence survival rate. Similar results were also found on the studies of Channos channos (Singh et al., 2011), Macrobrachium rosenbergii (Patil and Singh, 2014), Labeo rohita (Khati et al., 2015) and Oreochromis niloticus (Farraq et al. 2013; Manguti et al., 2014; Rostika et al. 2018). Water quality during the research was still in favorable condition to the cultivation of Sangkuriang Catfish (Clarias sp) fingerlings.

Parameters of water quality (temperature, $\mathrm{pH}, \mathrm{DO}$ and ammoniac) as presented in the Table. 3 were still in viable condition during the study for Sangkuriang Catfish (Clarias sp) fingerlings.

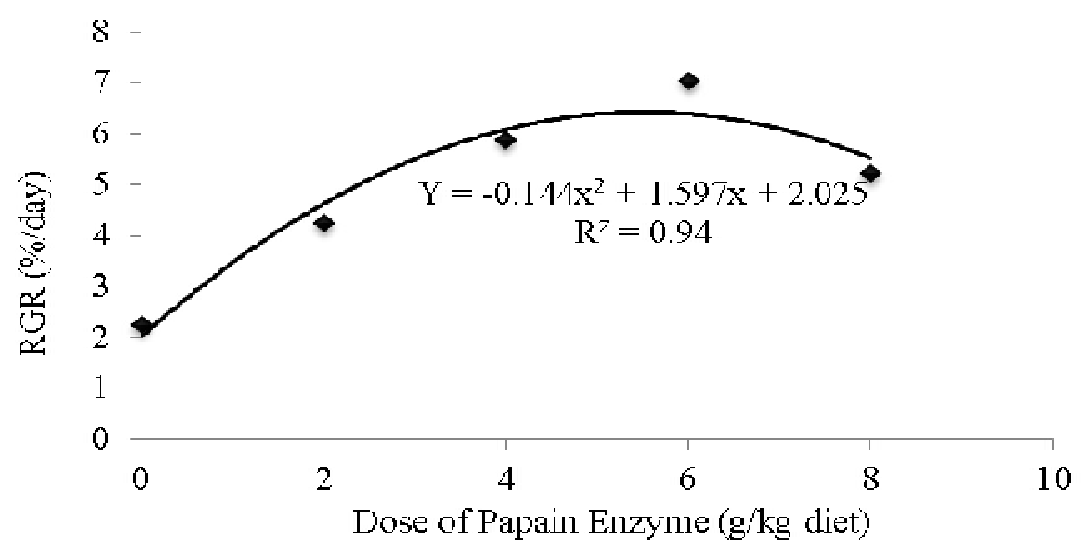

Figure 5. The relationship between papain enzyme supplement the feed and RGR of Sangkuriang Catfish (Clarias $s p$ ) fingerlings 
Table 3. Parameters of water quality for cultivation of Sangkuriang Catfish (Clarias $\mathrm{sp}$ ) fingerlings

\begin{tabular}{clccccc}
\hline No. & \multicolumn{1}{c}{ Variables } & A & Values B & C & D & Feasibility \\
\hline 1. & Temperature $\left({ }^{0} \mathrm{C}\right)$ & $26.15-28.05$ & $26.43-28.15$ & $6.23-28.21$ & $6.15-28.10$ & $25-32^{*}$ \\
2. & pH & $7.05-8.15$ & $7.24-8.23$ & $7.15-8.39$ & $7.16-8.52$ & $7-9^{*}$ \\
3. & DO $(\mathrm{mg} / \mathrm{L})$ & $3.25-4.87$ & $3.28-4.93$ & $3.82-4.86$ & $3.50-4.67$ & $3-6^{*}$ \\
4. & Ammoniac $(\mathrm{mg} / \mathrm{L})$ & $0.24-0.5$ & $0.24-0.5$ & $0.24-0.5$ & $0.25-0.5$ & $<1^{*}$ \\
\hline
\end{tabular}

Note: * Boyd, (1992)

\section{Conclusion}

It could be concluded that papain enzyme supplement increased protein digestibility and growth of Sangkuriang Catfish (Clarias sp) fingerlings. The dose of $6 \mathrm{~g}$ papain enzyme supplement per $\mathrm{kg}$ feed (treatment D) was the best dose for Sangkuriang Catfish (Clarias sp) fingerlings. The optimum doses of $A D C_{P}, E F U, F C R, P E R$ and $R G R$ in the Sangkuriang Catfish (Clarias $\mathrm{sp}$ ) fingerlings were $5.65,5.62,6.0,5.66$, and $6.0 \mathrm{~g} / \mathrm{kg}$ feed respectively.

\section{References}

Amri, E., Florence Mamboya. 2012. Papain, a plant enzyme of biological importance : a review. American Journal of Biochemistry and Biotechnology, 8 (2) : 99-104.

AOAC. 2016. Official Methods of Analysis 20th Edition. Association of Official Analytical Chemists, Washington D.C., pp. 1298.

APHA. 2005. Standard methods for examination of water and wastewater. 21st Edn. Washington DC, USA.

Center for Fresh Water Aquaculture (BBPBAT). 2010. Hatchery of Sangkuriang Catfish (Clarias sp). Ministry of Marines and Fisheries, West Java.

Boyd, C.E. 2003. Guidelines for aquaculture effluent management at the farm level. Aquaculture, $226: 101-112$.

Choi W. M., Lam C. L., Mo W. Y., Wong M. H. 2016. Upgrading food wastes by means of bromelain and papain to enhance growth and immunity of grass carp (Ctenopharyngodon idella). Environmental Science and Pollution Research, 23(8): 7186-7194.

Dabrowski K, Glogowski K.1977. A study of application of proteolytic enzymes to fish food. Aquaculture, 12: 249-360.
De Silva, S.S. 1987. Finfish nutrition research in Asia. Proceeding of The Second Asian Fish Nutrition Network Meeting, 128.

Farrag, F.H., F.F. Khalil, A.I. Mehrim., M.M.A. Refaey. 2013. Pawpaw (Carica papaya) Seeds Powder in Nile Tilapia (Oreochromis niloticus) Diet 1- Growth Performance, Survival, Feed Utilization, Carcass Composition of Fry and Fingerlings. Journal Animal and Poultry Prod, 4(6): $363-379$.

Fenucci, J.L. 1981. Studies on the nutrition of marine shrimp of the Penaeus. Ph.D. Thesis, Faculty of Department of Biology, University of Houston, Houston, Texas, USA.

Hepher, B. 1988. Nutrition of Pond Fishes. Cambridge University Press. New York. Pp 98.

Huet, M. 1970. Texbook of Fish Culture. Fishing News (Book Ltd.), London, 436 p.

Kazerani, H.R., Shahsavani. 2011. The Effect of Supplementation of Feed with Exogenous Enzymes on the Growth of Common Carp (Cyprinus carpio). Iranian Journal of Veterinary Research, 12 (2): 127-137.

Khati, A., M. Danish, K.S. Mehtaand N.N. Pandey. 2015. Estimation of growth parameters in fingerlings of Labeo rohita (Hamilton, 1822) fed with exogenous nutrizyme in Tarai region of Uttarakhand, India. African Journal of Agricultural Research, 10 (30): 30003007.

Lanari, D., Agaro E, Turri C. 1998. Use of nonlinear regression to evaluate the effects of phytase enzyme treatment of plant protein diets for rainbow trout (Oncorhynchus mykiss). Aquaculture, 161: 345-356.

Mo, W.Y., R.S.S. Lau, A.C.K. Kwok., M.H. Wong. 2016. Use of soybean meal and papain to partially replace animal protein 
for culturing three marine fish species: Fish growth and water quality. Environmental Pollution, (219): 815820.

Munguti, J.M., E.O Ogello, D. Liti, H. Waidbacher, M. Straif., Werner Zollitsch. 2014. Effects of pure and crude papain on the utilization and digestibility of diets containing hydrolysed feather meal by Nile tilapia (Oreochromis niloticus L.). International Journal of Advanced Research, 2 (6) : 809-822.

Muchlisin, Z.A., A. Fardin, M. Tanzil, F. Nur, J. Zulkarnain., A.A. Muhammadar. 2016. The effectiveness of experimental diet with varying levels of papain on the growth performance, survival rate and feed utilization of Keureling Fish (Tor tambra). Biosaintifika, 8 (2) : 172-177.

National Research Council. 2011. Nutrient Requirements of Fish and Shrimp. Washington, DC: The National Academies Press.

Olmos, J., Leonel Ochoa, Jesus PaniaguaMichel., Rosalia Contreras. 2011. Functional Feed Assessment on Litopenaeus vannamei Using 100\% Fish Meal Replacement by Soybean Meal, High Levels of Complex Carbohydrates and Bacillus Probiotic Strains. Journal Marine Drugs, 9, 1119-1132

Patil, D.W., H. Singh. 2014. Effect of papain supplemented diet on growth and survival of post-larvae of Macrobrachium rosenbergii. International Journal of Fisheries and Aquatic Studies, 1(6): 176-179.

Rachmawati, D,. Istiyanto, S., Maizirwan Mel. 2017. Effect of Phytase on Growth Performance, Diet UtilizationEfficiency and Nutrient Digestibility in Fingerlings of Chanos chanos (Forsskal 1775). Philippine Journal of Science, 146 (3):237-245.

Rostika. R., Sunarto, H. N. Sugiyanto., L. P. Dewanti. 2018. The effectiveness of crude papain enzyme supplement for tilapia's (Oreochromis niloticus) growth at the floating nets of Cirata Reservoir. IOP Conference Series: Earth and Environmental Science, 139

Singh, P, M. Sajid, H.S. Munir, P. Vikas, M. Danish, Ramesh., C. Singh. 2011. Exogenous supplementation of papain as growth promoter in diet of fingerlings of Cyprinus carpio. International Aquatic Research, 3: 1-9.

Spinelli J., Houle CR., Wekell JC. 1983. The effect of phytates on the growth of rainbow trout (Salmo gairdneri) fed purified diets containing varying quantities of calcium and magnesium. Aquaculture, 30: 71-83.

Steel, R.G.D., J.H. Torrie., D.A. Dickey. 1997. Principles and Procedures of Statistics: A Biometrical Approach. 3rd Edition, McGraw Hill, Inc. Book Co., New York, 352-358.

Steffens, W. 1989. Principles of fish nutrition. New York: Ellis horwood limited, John Willey and Sons.

Tacon, A.G.J., J.J. Cody., L.D. Conquest, S. Divakaran, I.P. Forster., O.E. Decamp. 2002. Effect of culture system on the nutrition and growth performance of Pacific white shrimp Litopenaeus vannamei (Boone) fed different diets. Aquaculture Nutrition, 8: 121-137.

Takeuchi, T. 1988. Laboratory Work Chemical Evaluation of Dietary Nutrient, p. 179 232. In: T. Watanabe (ed): Fish Nutrition and Mariculture. Kanagawa Fisheries Training Center, Japan Internasional Cooperation Agency, Tokyo.

Utomo, N.B.P, Susan., Mia Setiawati. 2013. Effects of fish meal made of various sources on the growth of Sangkuriang Catfish (Clarias $s p$ ). Jurnal Akuakultur Indonesia 12 (2), 158-168.

Wilson, R.P. 1982. Energy relationships in catfish diets. In: Nutrition and Feeding of Channel Catfish. Stickney, R.R. \& R.T. Lovell (Ed.). Southern Cooperative Series, Auburn, Alabama, pp. 193-201.

Wong, M.H, Tang LY., Kwok FSL. 1996. The use of enzyme digested soyaben residue for feeding common carp. J Biol, Hong Kong Bapist University, Kowloon Tong, Hong Kong, 9 : 418-42.

Yakuputiyage, A. On-farm feeding and feed management strategies in tropical aquaculture. 2013. In: On-Farm Feeding and Feed Management in Aquaculture. Hasan M.R. \& M.B. New (Ed.). FAO Fisheries and Aquaculture Technical Paper No. 583. Rome, FAO. pp. 361-376. 